\title{
Hereditary cryohydrocytosis with normal stomatin
}

INSERM

\section{Source}

INSERM. (1999). Orphanet: an online rare disease and orphan drug data base. Hereditary cryohydrocytosis with normal stomatin. ORPHA:398088

Hereditary cryohydrocytosis with normal stomatin is a rare, hereditary, hemolytic anemia due to a red cell membrane anomaly characterized by fatigue, mild anemia and pseudohyperkalemia due to a potassium leak from the red blood cells. A hallmark of this condition is that red blood cells lyse on storage at 4 degrees centigrade. 